\title{
Academic Underachievement of Learners at School: A Literature Review
}

\author{
Nooe Esther Chere \\ School of Education Studies, Faculty of Education \\ University of the Free State \\ Dipane Hlalele \\ School of Education Studies, Faculty of Education \\ University of the Free State, Qwaqwa campus \\ Email: hlaleledj@qwa.ufs.ac.za
}

\section{Doi:10.5901/mjss.2014.v5n23p827}

\begin{abstract}
This paper provides an account of academic underachievement using a literature review. It begins by describing what academic underachievement is as a global conern. Different etiological models, characteristics, types and symptoms of academic underachievers are discussed. The paper concludes with a dsicussion of school-related factors affecting acadeimc underachievement. We conclude by noting that learners need to be made aware of the existence of academic underachievment and that the phenomenon is pervasive but can be dealt with.
\end{abstract}

Keywords: academic underachievement, symptoms, etiological models, characteristics

\section{Introduction}

Several factors are suspected to affect academic underachievement. These have been primarily arranged into two clusters, namely personal or individual-related factors and environmental factors. The personal factors may be physical, intellectual or emotional, and environmental factors comprise factors within the school or family. This paper focuses on academic underachievement, academic underachievers and the school-related factors affecting academic underachievement. Matthews and McBee (2007:168) mention that one frequently used explanation of underachievement suggests that underachievement of learners is caused by the school environment.

\section{Academic Underachievement}

The issue of academic underachievement is one of great concern, especially because it is not a problem only among gifted learners but prevails at all ability levels. Rayneri, Gerber and Wiley (2006:104) mention that academic underachievement is a national problem in the United States. In addition, Matthews and McBee (2007:167) indicate that the topic of underachievement has intrigued educators for quite some time and is an ongoing concern. It seems that there is little consensus on how best to define underachievement. Donald et al. (2006:207) define academic underachievement as performing below potential while Reis and McCoach $(2000: 153,157)$ define it as a discrepancy between ability and achievement.

From these varying definitions it can be deduced that underachievers are a diverse population, and that both gifted and non-gifted learners can underachieve. In general, academic underachievement is defined as failure to meet the academic requirements of the school setting (Connor, 2002:133). One might think that underachieving learners lack motivation, but Mandel and Marcus (as cited in Reiss, 2008:85) assert that underachievers are, in fact, highly motivated in directions other than getting good grades. This acknowledges that academic underachievement can also result from extracurricular circumstances that distract youngsters from paying attention to their schoolwork. Young people who fail to utilize their potential waste educational and occupational opportunities that are within their reach.

\section{Etiologic Models of Academic Underachievement}

Matthews and McBee (2007:167) question how it can be explained that an otherwise capable or highly achieving able 
student fails to do well in school. This is an indication that researchers are trying hard to find reasons why even highly able learners underachieve. It is not completely understood why capable learners underachieve, and many, including teachers, often mistakenly assume that underachievement is a simple problem that can only be associated with failure to work to potential.

Butler-Por (as cited in Westminster Institute of Education, 2006:1) argues that underachievement is not caused primarily by inability to do better, but by either a conscious or unconscious choice. Baker et al. add: "Currently we have several models in the theoretical literature attempting to describe origins of under-achievement among learners. Typically, individual, family and school related factors are discussed as contributing to problems of underachievement." Three models can be used to predict underachievement status among underachieving learners. Those are the individual, family and school etiologic models.

\subsection{Individual etiologic model}

Based in the "medical model" tradition within psychology and education, the individual difference approach holds that the roots of underachievement lie within the child (Baker et al., 1998:1). From this perspective underachievement is usually attributed to motivational or behavioural/emotional problems on the part of the learner. Weaknesses in the academic and "school survival" skills also contribute to problems of underachievement (Krouse \& Krouse as cited in Baker et al., 1998:1). School readiness may be implicated in underachievement among learners.

\subsection{Family etiologic model}

The family systems perspective understands behaviour as being influenced by relationships and interactions with others within the family (Baker et al., 1998:2).From this perspective underachievement derives from the family's inability to adequately support the child. Rimm and Lowe (as cited in Baker et al., 1998:2) state that, although families of underachievers are as active and busy as the families of achievers, they seem to have more trouble managing their schedules. From this perspective, lack of a supportively structured environment in which achievement can flourish, as well as parental modelling of poor organization, may contribute to underachievement. Independence is another aspect of the family climate that does not appear to be facilitated within families of underachievers. The general consensus within the literature is that families of achievers and underachievers exhibit differences in variables important to supporting children's behaviour. The family influences a child's achievement, and underachievement results from disturbances within the child's family system.

\subsection{School etiologic model}

After the family, the other major context for children's' development is the school. From this perspective, a mismatch between the needs of the child and the environment of the school are implicated in the problem of learner underachievement. A mismatch between pedagogical approaches and children's learning styles may also promote underachievement if students are not provided with encouragement or viable ways of expressing their talents (Redding \& Whitmore as cited in Baker et al., 1998:3). Inflexible curricular requirements, age-grouping, and lack of acceleration opportunities are also cited in reference to underachievement. Wearmouth, Richmond, Glynn and Berryman (2004:4) note that one of the prime responsibilities of the school is to support the reconstruction of a student's sense of self through an acknowledgement of agency and the development of self-esteem.

\section{Characteristics of Academic Underachievers}

Interestingly, some recent research suggests that underachieving gifted students share more characteristics with underachievers in general than they do with achieving gifted students (Dowdall \& Colangelo; McCall, Evahn \& Kratzer as cited in Reis \& McCoach, 2000:158). If underachievers have common characteristics, it might be possible for them to be identified and supported.

\subsection{Personality characteristics}

Personality can be defined as a dynamic and organized set of characteristics possessed by a person that uniquely influence the person's cognition, motivation, and behaviour. Henley, Ramsey and Algozzine (2002:120) indicate that most 
students with social and emotional difficulties do not like school. This stipulates that some personality characteristics can be implicated in academic underachievement. Learners with emotional or behavioural disorders often underachieve.

\subsection{Self-esteem}

Reis and McCoach (2000:159) assert that academic underachievers have low self-esteem, low self-concept, and low selfefficacy. Self-esteem reflects a person's overall evaluation or appraisal of his own work. It encompasses beliefs and emotions, and the behaviour displayed by the person reflects the person's self-esteem. Vaughn et al. (2007:252) indicate that individuals with positive self-concept generally feel as though they are worthwhile and deserve respect. It can be concluded that those learners whose self-concept is low do not believe in their own ability to do better in school and are, therefore, in danger of underachieving.

\subsection{Social withdrawal}

Reis and McCoach (2000:159) indicate that academic underachievers are alienated or withdrawn, distrustful or pessimistic. Vaughn et al. (2007:128) contend that withdrawal describes the typical behaviour of students who are anxious or depressed. They frequently withdraw from others and appear reclusive, preferring solitary activities. These learners exhibit internalizing emotional and behavioural problems and may choose to withdraw themselves in order to avoid situations that arouse emotions or to keep their emotions out of awareness of others. Because they are alienated, they may have feelings of hopelessness and pessimism.

\subsection{Anxiety and attention deficit hyperactive disorder}

Reis and McCoach (2000:159) contend that academic underachievers who are anxious, impulsive, inattentive, hyperactive, or easily distracted may exhibit ADD or ADHD symptoms. Anxiety is defined as an unpleasant emotional state resulting from stress or conflict and characterized by fear or apprehension. Overwhelming anxiety can disrupt academic functioning and leads to academic underachievement. Learners with ADHD have problems with paying attention in class for a long time and are easily distracted. The association between underachievement and ADHD is well documented by different authors. Nairne (2003:2004) indicates that, in addition to having attention problems which affect quality of their schoolwork, children with this disorder are often hyperactive and impulsive, while Boyd and Bee (2006:254) maintains that children with ADHD are more physically active and/or less attentive than their peers and that these characteristics often lead to both academic and behavioural problems at school.

\subsection{Aggressive behaviour}

Academic underachievers may demonstrate externalizing behaviours. Academic underachievers are aggressive, hostile, resentful, or touchy (Reis \& McCoach, 2000:159). Aggression is a forceful, verbal or physical action which may be appropriate and self-protective or inappropriate as in hostile or destructible behaviour. Boyd and Bee (2006:214) mention that the most common definition of aggression is behaviour apparently intended to injure another person or damage an object. Hostile learners always look for trouble. They can get themselves into so much trouble that they are distracted from their school work, leading to grades below their capacity (Reiss, 2008:91). Poor adjustment to high school characterised by dropping out and failing grades is a characteristic of aggressive learners. Aggressive learners may also be resentful. Resentment is an emotion of anger or bitterness felt repeatedly as a result of real or imaged wrong done.

\subsection{Depression}

Reis and McCoach (2000:159) express the opinion that academic underachievers are depressed. Among others, as indicated in Sue, Sue and Sue (2006:355), depression is marked by the inability to concentrate, negative thinking and low energy levels. Depression thus interferes with normal life functioning including academic functioning. Young people who cannot think clearly or maintain a normal energy level will understandably have difficulty earning grades that are commensurate with their intelligence in school. Schroeder and Gordon (2002:311) acknowledge that depressed children often present academic difficulties even though it is not known whether school problems are antecedents or consequences of depression. 


\subsection{Social orientation}

Reis and McCoach (2000:159) state that academic underachievers are more socially than academically oriented. They may be extroverted, easygoing, considerate, and/or unassuming. An extrovert is a bold, outgoing person whose attention is directed outwards (Coon, 2002:360). These learners may see no need for learning as their focus may be directed outside of the classroom. They are not worried about schoolwork and will not draw attention to it. They see themselves as having other tasks to do. Reiss (2008:92) describes them as expedient learners. The author indicates that expedient students see nothing wrong in breaking promises when opportunities come, and are disloyal, irresponsible and untrustworthy. These learners usually underachieve when they avoid their schoolwork and other related responsibilities.

\subsection{Resilience and dependency}

Academic underachievers are dependent and less resilient than high achievers (Reis \& McCoach, 2000:159). Dacey and Travers (2004:407) indicate that resilience is defined as the ability to recover from highly stressful situations and as those individuals who deal well with stress, who have few psychological, behavioural, or learning problems. Resilient children have one or more advantages to overcome their problems. According to Santrock (2003:149) these advantages include individual factors (such as good intellectual functioning), family factors (such a close, caring relationship with at least one parent) and extra-familial factors (such as bonds with supportive, competent adults outside the family). If children do not have these advantages they are less likely to be resilient or recover from stressful situations. Less resilient children are therefore less likely to do well in school. Resilient children are likely to have high self-esteem and self-confidence. People with high self-confidence are less dependent on others. On the other hand, people with dependent personalities lack selfconfidence. They make others run their lives and make no demands on them so as not to endanger these protective relationships. Learners who are overly dependent on teachers or other learners feel helpless on their own and are likely to underachieve.

\subsection{Fear of failure}

Reis and McCoach (2000:159) state: "Underachievers exhibit fear of failure; gifted underachievers may avoid competition or challenging situations to protect their self-image or their ability." Learners who are not motivated to achieve may have a strong fear of failure. Passer and Smith (2004:349) contend that people with high overall achievement motivation (called high-need achievers) have a strong motive for success and a weak fear of failure, but low achievers display the opposite pattern. Learners who fear failure rarely take risks. They avoid challenging situations or do less well in challenging tasks. McCland (as cited in Passer \& Smith, 2004:349) writes that when tasks are challenging or the importance of doing well is stressed, high-need achievers outshine low-need achievers. Fear of being criticized leads to the avoidance of challenging classroom tasks and interacting with other learners. High scores on the basic desire for acceptance indicate an above average fear of failure and lack of confidence (Reiss, 2008:91). Because they fear failure, these learners are inclined to set high goals for themselves and then work only half-heartedly to attain these goals. This allows underachieving learners to deny any limitations they may have and to dismiss any suggestions that they are actually a failure.

\subsection{Fear of success}

Reis and McCoach (2000:159) posit that academic underachievers display fear of success. Learners who fear success are concerned that doing well will bring them more unhappiness than will failing to achieve. Young people who fear success might make light of their own abilities even when they are considerable; they set limited, unrealistic goals that are easily within their reach; and they put just enough effort to reach these minimal goals. Adolescents sometimes fear that their achievement will be envied or resented by their peers. They want to gain peer acceptance through not doing well in their studies. In this case the children's peers are chief determinants of how much effort they dedicate to their learning.

\subsection{Locus of control}

Locus of control refers to the extent to which individuals believe they can control events that affect them. Individuals with an internal locus of control believe that they can control their lives and assume that their efforts will be successful. Those with an external locus of control believe that their environment, some higher order, or other people control their decisions 
and life. According to Donald et al. (2006:173) someone with a strong external locus of control feels that he has little or no control over what happens in his life and does not believe in himself. What happens in the life of someone with a strong external locus of control is seen as due to chance or luck or fate. Learners with an external locus of control tend to be overly dependent on teachers other learners. They do not believe in their own ability and they feel excessively passive and helpless on their own.

\subsection{Attitude towards school}

Academic underachievers have negative attitudes towards school (Reis \& McCoach 2000:159). Rathus (2002:579) states: "Attitudes give rise to cognitive evaluations (such as approval or disapproval), feelings (liking, disliking or something stronger), and behavioural tendencies (such as approach or avoidance)." If the performance at school is deemed inadequate, learners may also perceive themselves inadequate in other kinds of learning experiences. As this experience continues, a negative attitude towards school and learning in general may result. Because academic underachievers do not only suffer from poor grades, but also from disapproval of parents and teachers, they are likely to disapprove of, dislike and avoid school. Truancy and other non-compliant behaviours at school can therefore be expected from underachievers.

\subsection{Differential thinking skills/styles}

The thinking styles of academic underachievers differ from those of achieving learners. Santrock (2003:353) describes thinking as involving the manipulation ofinformation, as in concept formation, problem solving, critical thinking, reasoning and decision making, while Mayer (as cited in Pastorino \& Doyle-Portillo, 2006:300) defines thinking as the use of knowledge to accomplish some sort of goal to perceive and understand our world, to communicate with others, and to solve problems we encounter in our lives. Thinking involves storing perceived information and remembering it. Academic underachievement may result from a lack of strategies to store information in the long-term memory as mental representation. Pastorino and Doyle-Portillo (2006:300) describe mental representation as bits of memory that represent objects, events, people and so on that are not actually present now.

\subsubsection{Convergent thinking skills}

Reis and McCoach (2000:159) caution that academic underachievers perform less well on tasks that require detailoriented or convergent thinking skills than their achieving counterparts. Papalia et al. (2003:235) describe convergent thinking as thinking aimed at the one correct answer to the problem while divergent thinking produces a variety of novel, diverse possibilities. For example, a learner uses convergent thinking to arrive at the correct answer to a multiple-choice, true/false or recall question. Rathus (2006:425) contends that in convergent thinking thought is limited to present facts; the problem solver narrows his or her thinking to find the best solution. Academic underachievers are not able to provide detailed or exact answers but tend to go wide when answering questions. They might do better when tasks require divergent thinking skills. Rathus (2002:237-238) posits that in divergent thinking the problem solver associates freely to the elements of the problem, allowing "leads" to run a nearly limitless course.

\subsubsection{Performance on sequential tasks}

Reis and McCoach (2000:160) express the opinion that academic underachievers score lower on sequential tasks such as repeating digits repeating sentences, coding, computation, and spelling. Sequential tasks require learners to recall information. Academic underachievers have problems with memorizing details. They may require information to be repeated several times before they grasp and retain it. According to Santrock (2003:306), memory is the retention of information over time through encoding, storage and retrieval. In other words, for memory to work, a learner has to take information in, store it or represent in some manner, and then retrieve it for some purpose later on. In order for memory to work, children need to use strategies to help them remember. Papalia et al. (2003:305) mention these strategies as selective attention - the ability to consciously direct attention and exclude unwanted intrusion, and mnemonic strategies mental "tricks" or devices to aid memory. 


\subsubsection{Insight and critical ability}

Reis and McCoach (2000:160) state that academic underachievers lack insight or critical ability. Academic underachievers cannot generate meaning or understanding by relating new information to the prior knowledge. Vaughn et al. (2007:440) mentions that in critical thinking, both sides of an issue are examined before making a judgment. Critical thinking refers to reasonable, reflective thinking that is focused on deciding what to believe or do. When a learner thinks critically, the learner analyzes arguments, carefully sees other points of view, and reaches sound conclusions (Kizlik, 2009).

\subsection{Maladaptive strategies}

Academic underachievers use maladaptive strategies. According to Reber and Reber (2001) adaptive means appropriate, useful, aiding in adjustment. Maladaptive strategies therefore refer to strategies that are unsuitable or improper for normal functioning or survival.

\subsubsection{Goal setting}

Reis and McCoach (2000:160) mention that academic underachievers lack goal-directed behaviour and fail to set realistic goals for themselves. Underachievers engage in purposeless learning because they fail to set goals for themselves. Goal-setting, panning and self-monitoring are critical aspects of achievement (Pintrich and Schunk as cited in Santrock, 2003:448). Setting goals help individuals to monitor themselves and engage goal-directed behaviour. It helps individuals to increase their self-discipline and maintain interest. Researchers have found that high-achieving individuals monitor their own learning and systematically evaluate their own progress toward their goals more than low-achieving individuals (Zimmerman as cited in Santrock, 2003:448). Setting no goals or setting unrealistic goals causes academic underachievement.

\subsubsection{Coping mechanisms}

Reis and McCoach (2000:160) believes that academic underachievers possess poor coping skills and that they develop coping mechanisms that reduce short-term stress, but inhibit long-term success. Academic underachievers are likely to engage in emotion-focused coping strategies. Pastorino and Doyle-Portillo (2006:594) state that emotion-focused coping is aimed at controlling internal, subjective, emotional reactions to stress and altering feelings or thoughts in order to reduce stress. In trying to cope with stress, underachievers might avoid classes, and pretend as though classes do not matter. This they may do to control anxiety generated by feelings and thoughts of failure. Emotion-focused coping mechanisms do not eliminate the stressors as opposed to problem-focused coping skills that focus on the problem to bring long-term stress. Emotion-focused coping strategies are likely to reduce stress on the short-term basis but inhibit long-term success. On the contrary, in problem-focused coping, an individual focuses on the problem. Pastorino and Doyle-Portillo (2006:594) posit that problem-focused coping focuses on changing the situation that causes stress to reduce the amount of perceived stress. Lack of skill or ability to focus on the problem may result in academic underachievement.

\subsubsection{Control of emotions}

Academic underachievers possess poor self-regulation strategies, show low tolerance for frustration, lack perseverance, and lack self-control (Reis \& McCoach, 2000:160). Fagen and Long (as cited in Henley et al., 2002:351) define selfcontrol as the ability to direct or control personal behaviour flexibly and realistically in a given situation. It is one's ability to remain calm and not show one's emotions. A learner with lack of self-control may behave impulsively. Impulsive behaviour causes classroom disruption and is a sign of low tolerance for frustration. Boyd and Bee (2006:246) maintains that children's ability to exercise control over their emotions in early childhood is strongly related to measures of academic achievement in high school. High-need achievers persist longer after encountering difficulty than do low-need achievers, but in general they do not outperform low-need achievers when conditions are relaxed and tasks are easy (McCland \& Atkinson as cited in Passer \& Smith, 2004:349). This indicates that academic underachievers lack perseverance, especially in challenging tasks and that they easily give up. 


\subsubsection{Defence mechanisms}

According to Reis and McCoach (2000:160) academic underachievers use defence mechanisms. Stated in Nairne (2003:422) as well as Boyd and Bee (2006:24), Freud proposes that the ego uses a variety of defence mechanisms, which are unconscious processes that ward off the anxiety that comes from confrontation with the id. Defence mechanisms are brought into play by various entities to cope with reality and to maintain self-image. They serve to provide relief from anxiety and emotional conflicts. Underachieving learners may use defence mechanisms to cope with anxiety generated by failure. They may deny that they have academic problems, create reasons for their failure, blame teachers for their problem or displace their anxiety on other learners by acting aggressively.

\subsection{Positive attributes}

Although academic underachievers have many undesirable attributes, they have characteristics that can still be valued.

\subsubsection{Interest and commitment}

Reis and McCoach (2000:160) maintain that academic underachievers show intense outside interest and are committed to self-selected work. Although academic underachievers may not be interested in schoolwork, they are not necessarily unmotivated in every respect. Varvil-Weld (n.d.) states that these youngsters may be highly motivated in certain areas of their lives, but not necessarily in areas that are important to their parents and teachers. For example, many academic underachievers may be highly socially motivated. Thus their social life is very important to them, and they can work very hard to be successful at it. Academic underachievers may be described as being intellectually incurious. According to Reiss (2008:89), people who lack intellectual curiosity have the potential to value knowledge they can put into use. They are not interested in theoretical ideas but in practical ideas. The self-selected work often does not involve theoretical ideas, but practical ideas.

\subsubsection{Creativity}

Reis and McCoach (2000:160) indicate that academic underachievers can be creative learners. Thus academic underachievers can be creative problem solvers. However, this does not necessarily mean that underachievers are more creative than able learners. A creative person would have high academic ability of the sort measured on intelligence tests (Rathus, 2002:238). High achievers rate high on achievement tests, therefore they are more creative than low achievers. Rathus (2002:237) posits that creative problem solving demands divergent rather than convergent thinkers. Therefore if academic underachievers can be learners creative, they are more likely to be divergent thinkers than convergent thinkers.

\section{Types of Academic Underachievers}

Academic underachievers are a diverse population displaying different characteristics. There is an overlapping of characteristics. Some characteristics may be shared by different types of underachievers. Reis and McCoach (2000:161) describe different types of underachievers as follows.

\subsection{The Stressed Learner/“Perfectionist Pearl” Dependent Conformer/Anxious Underachiever}

These underachievers are anxious, perfectionists and worried about failure. These learners are typically described as anxious and insecure. They are worried about details, have a high level of self-doubt and experience high level of tension that interferes with their ability to concentrate and do their best work (Marcus, 2007). This overwhelming anxiety disrupts their academic functioning. Sue, Sue and Sue (2003:128) express the opinion that something would be wrong if an individual does not feel some anxiety in facing day-to-day stressors; however, overwhelming anxiety can disrupt social and occupational functioning or produce significant distress. Anxious learners may avoid school and have complaints of physical ailments. Sue et al. (2003:130) contend that individuals with overwhelming anxiety may take the form of avoiding anxiety-provoking situations, and manifest some somatic problems. 


\section{2 "Manipulative Mary" Dominant Non-conformer/Wheeler-dealer Underachiever}

Though they seem very charming and friendly, these underachievers are irresponsible and get into trouble, often by doing things that break rules or are otherwise improper (Marcus: 2007). They are manipulative, insecure and have poor selfconcept. Their interest is outside the classroom and social life, but their friendships are unstable. They have no patience, especially to do the kind of quiet and persistent thinking and attention that schoolwork requires and put little effort in their school work. They lie, steal or cheat.

\subsection{The Complacent Learner/“Passive Paul” Dependent Conformer/Coasting Underachiever}

These underachievers procrastinate, are easily distracted from doing work, and seem unconcerned about schoolwork. They procrastinate, not only with schoolwork, but also with household chores and personal responsibilities, and are thought as being lazy and lacking motivation. They have vague explanations for poor academic performance an always seem to have an excuse for not doing their schoolwork. Marcus (2007) mentions that these are the most common style, but a puzzle to teachers, counsellors, parents, and they do not respond to the usual approaches such as counselling, rewards and punishments, medication and tutoring.

\subsection{The Rebel/“Rebellious Rebecca” Dominant Non-conformer/ Defiant Underachiever}

The oppositional underachievers often have a defiant and angry attitude towards others and are constantly negative towards the authority figures around them (Marcus, 2007). These underachievers might be learners with emotional or behavioural problems. Landrum, Tankersley and Kauffman (2003:148) assert that students with disabilities experience poorer outcomes than do their non-disabled peers, but for students with emotional or behavioural problems in particular the outlook for school and later life success has historically been quite bleak. There is an association between academic underachievement and antisocial behaviour patterns in youth, and the two determine each other. Sue et al. (2003:508) write that children with oppositional defiant disorder often lose their temper, argue with adults, and they defy or refuse adult's requests. The defiant children fail to learn to respect authority, and this failure generalizes to the school setting and results in academic underachievement.

\section{5 "Creative Chris" Dominant Non-conformer"/The Identity Search Underachiever}

These learners are very thoughtful, confused, and independent. They are so wrapped up in searching for an identity that they become distracted from their school work. They are typically at a point in adolescence or early adulthood in which they try to figure out who they are, where they are going, and what life means (Marcus, 2007). In their intense focus on these issues, they may not want to conform and academic achievement is not a primary consideration.

\section{6 "Depressed Donna" Dependent Non-conformer/The Sad or Depressed Underachiever}

These underachievers are sad, depressed and have low self-esteem. Learners who experience emotional distress are affected in a number of ways. Adolescent depression is associated with persistent anxiety, poor school performance, drug abuse, law breaking, and auto accidents (Berk, 2002:628). Depression in learners may result in apathy, poor appetite or overeating, too much sleeping or trouble sleeping, low energy levels, and feelings of hopelessness and pessimism. It is unlikely for learners with these kinds of symptoms to do well at school. Cooley (2007:14) indicates that depressed learners can have their academic performance suffer, as can self-concept and relationships with others, and inappropriate behaviour can jeopardize a student's placement in a classroom or school.

\section{School and Classroom Environment Affecting Academic Underachievement of Learners}

Matthews and McBee (2007:168) mention that one frequently used explanation suggests that underachievement of learners is caused by the school environment. The classroom is a subsystem of the school. Just like the school, the classroom has its own culture. Classroom culture refers to the way things are in a particular classroom. Donald et al. (2006:140) mention that a classroom often has a characteristic atmosphere related to its culture: it may be accepting, busy, co-operative place; a silent, passive place dominated by teachers; or a chaotic place with no discipline. Donald et al. (2006:141) describe a positive classroom environment as the one that matches learner's needs and values. The 
school environment must be positive for the enhancement of learning. An environment in which learning takes place may have an influence on learner motivation. Pretorius (as cited in Olivier, 2006:53) contends that poor motivational patterns and socially deviant behaviours can be attributed to environmental factors. The school as an educational environment impacts on the motivational state of learners, but the school environment, like the home environment, can be deprived. Environmental deprivation refers to the conditions in both the school and the home that make it difficult for learners to satisfy their needs and fully reach their potential. Learners from a deprived school environment lack motivation to learn, and are in danger of negative behaviours and unsatisfactory academic achievements.

\subsection{School management}

Essentially, the process of management is concerned with the transformation of schools so that ultimately effective learning may take place (Thurlow, 2003:35). Quality management can be measured in terms of the degree of cooperation among teachers, and collaboration between teachers and parents. Mda and Mothata (2000:68) believe that not only the principal is responsible for the daily running of the school by stressing that management refers to the day-to-day organization of teaching and learning, and the activities that support teaching and learning, and that teachers and school principal are responsible for these activities. In addressing the issue of and collective management and of transformation schools for effective learning, some governments have set up school governing structures and systems. Cross, Mungadi and Rouhani (2002:171) state: "South Africa has excelled in setting up a new governance system which encourages local and community participation in schools through school governing bodies (SGBs) comprising teachers, learners, parents and other relevant stakeholders..." The task of the SGBs is to establish and maintain order within the schools, so that teaching and learning take place effectively.

\subsection{Physical environment and infrastructure}

It is believed that a well-structured physical environment and infrastructure create a positive learning atmosphere. Hardiman (2003:40) states: "Educators must also understand how the physical learning environment speaks volumes to our children, parents and the community about our philosophy, expectations, and approach to instruction." Learners in carefully planned learning environments demonstrate better attendance, discipline, and general health than those in lessinviting environments. Bowers and Burkett (as cited in Hardiman, 2003:39) point out that students who attend schools and classrooms with an optimal physical learning environment performs significantly better in reading, listening, language and arithmetic. Education for All (2000:48) indicates that infrastructure rehabilitation or improvements have high spin-offs, such as attraction and retention of good educators leading to high morale among staff, learners and the community. Quality of secondary education is greatly affected by a lack of or poor facilities. World Data on Education (2006:3) indicates that in Lesotho many schools are affected by lack of special facilities such as libraries and laboratories which help to enrich quality of secondary education. Rural areas are particularly disadvantaged. For instance, in the mountains, where teaching is unpopular and school facilities inferior, examination pass rates are lowest (Gay, Gill, Green, Hall, Mhlanga \& Mohapi as cited in Ansell, 2002:92).

\subsection{Relationship between the learner and the curriculum, and the acceleration of opportunities}

Boredom is more likely to be experienced by the more able learners than the less able ones. In classrooms where a single curriculum is covered by all learners, some of these learners may find school restrictive, frustrating and uninspiring. When learners feel uninspired or unmotivated, they might not perform to their abilities. Diaz (as cited in Rayneri, Gerber \& Wiley, 2006:105) express that an elementary school curriculum that is dull and unchallenging does not encourage bright students to develop necessary skills that will be needed later in middle and high school. Hong, Greene and Higgins (2006:92) conclude that, although teachers are willing to include mainstream students within whole class activities and provide encouragement and support for their academic success, they are less willing to make specific modifications to their instructional practices, use differentiated curricular materials, or provide a classroom environment to meet the needs of mainstreamed students. The school curriculum should be dynamic, match the needs and interests of all learners, and be designed in such a way that it will develop the learners' skills, abilities and interests.

\subsection{Relationship between instructional styles and learning styles}

Dunn \& Dunn (as cited in Rayneri et al., 2006:105) define one's learning style as the way an individual processes, 
interacts with, and retains new or difficult information. It is one's approach to learning. Individual learners have different preferred styles to learning. Child (2004:316) stresses that the concept of learning style in education is important because it incorporates all those human attributes which help to determine and characterize a person's preferred approach to problem-solving. Instructional styles that do not match with learning styles might result in academic underachievement. Law and Glover (2000:170-171) emphasizes that a poor match between teaching strategy and learning style(s) can inhibit student achievement, can provoke misinterpretation about potential and encourage behaviour problems.

\subsection{Teacher-learner ratio and class size}

Bukatko and Daehler (2004:588) indicate that class size is another important aspect of school structure, and Berk (2002:464) stresses that a large-scale field experiment revealed that class size influences children's learning. Teachers also have more time to spend with individual children, and students are more likely to be attentive and engaged in classroom activities and show fewer behaviour problems. Small class size makes both teachers and learners satisfied with school experiences while large classes cause disengagement of both teachers and learners. Berk (2002:464) believes that small class size is beneficial because teachers of fewer children spend less time disciplining and more time giving individual attention, and children's interactions with one another are more positive and cooperative.

\subsection{Teacher-learner relationships}

Overall and Sangster (2003:148) mention that beyond achievement in the subject, learners want teachers to be approachable and take interest in them, and know them as people. If teachers fail to provide in these needs, good relationships between teachers and learners cannot be created or maintained. Disturbed teacher-learner relationships and misunderstanding between teachers and learners might result in academic underachievement. Knowing each learner in a classroom creates a direct relationship between the teacher and each learner. Kerry and Wilding (2004:84) believe that the basic aim of knowing each learner is to connect at some level with every child in the class. As much as poor teacher-learner relationships develop perhaps as result of children's challenging behaviour, some teachers' behaviour such as stereotypes of giftedness may contribute to poor teacher-learner relationships as well. Weiner (as cited in Baker et al., 1998:4) thinks that teachers are typically more punishing of students whom they perceive as failing due to lack of effort rather than lack of ability. Teachers may also tend to be more tolerant to challenging behaviour or failure from less gifted learners than from more gifted ones.

\subsection{Teacher attitudes and expectations}

Fike and Hewstone (as cited in Woolfolk, 2005:44) state: "Expectations and beliefs focus attention and organic memory." Teachers fail to recognize talent, especially among less talented learners or those with behaviour problems, and hold low performance expectations for them. On the other hand, teachers may hold high expectations for talented learners which may not always be met by these learners. Pendarvis (as cited in Baker et al., 1998:2) states that teachers may hold stereotypes about gifted students and have unreasonable high standards of performance, thereby eliciting withdrawal and failure to perform by gifted students who pursue undue pressure. Expectations can be self-fulfilling. Woolfolk (2005:447) indicates that in self-fulfilling prophecy, the teacher's beliefs about students' abilities have no basis, but student behaviour comes to match the initially inaccurate expectations. Though expectations may be inaccurate, they determine how teachers view and interact with the learners. Brophy and Alleman (2007:321-322) indicates that teachers should form and project expectations that are positive as they can be while still remaining realistic, and should hold learners accountable for participating in lessons and learning activities and turning in careful and completed work on assignments.

\subsection{Teacher effectiveness and performance}

Teachers should have broad-based knowledge of the content to impart knowledge well to the learners to increase the academic performance of learners. Holt and Kysilka (2006:7) state: "When you have knowledge of subjects you are expected to teach, you are better equipped to help students learn." Good teachers recognize that every learner is unique, and deserves and requires special attention and adaptation of the learning experience. Good teaching is about recognizing and selecting instructional patterns that match the context for learning and the students being taught (Holt \& Kysilka, 2006:22). This implies that a teacher has other roles to play, though undeniably the most important role of the teacher in the modern classroom is still of a director of learning activities and no longer of transmitter of information. 
Teachers are now expected to take on more responsibilities for student academic growth, to tailor curriculum and assessment to student and community needs, and even to help manage their schools (George, McEwin \& Jenkins, 2000:298).

\subsection{Language of instruction}

According to Prah (2005:27), the language of instruction (Lol), or language in which education is principally conducted, is one of the most far-reaching and significant features of any education system. It is the language used for imparting basic skills and knowledge to learners. Prah further asserts that it is in the Lol that knowledge is accumulated and deposited. It is therefore necessary that learners acquire the basics of the Lol at an early age. It takes longer to master second language for academic or literacy purposes than for face-to-communication. It is indicated by Woolfolk (2005:178-179) that it takes students about two to three years in a good quality program to be able to communicate face-to-face in a second language, but mastering de-contexualised, academic language skills in the new language takes five to seven years. This might explain why learners who seem comfortable in face-to-face conversation in a second language still have great difficulty with complex school work. In most African countries today, the mention of a language as medium of instruction immediately conjures up the image of classes in which children are taught either in African language or, more usually, an imported official language such as English or French (Bamgbose, 2002:75).

\subsection{Peer relationships}

Reis and McCoach (2000:160) indicate that positive peer interactions contribute to some students' reversal of underachievement but negative peer attitudes can often account for underachievement. Adolescents sometimes however tend to be highly peer-orientated to an extent that they avoid being successful in their studies in order to gain peer acceptance. They choose to underachieve to avoid rejection by peers. A desire to conform to group standards may make even the academic able learners to deflect attention away from their academic ability. Peer rejection causes unhappiness, alienation, poor academic achievement and low sense of self-esteem in children. Children who are excluded by their peers have more trouble engaging in activities than children who are not excluded and they are likely to withdraw from classroom activities and suffer academically. Berk (2002:498) as well as Parker \& Asher (as cited in Mikami, Boucher \& Humphrey, 2005:6) emphasize that peer rejected children are more likely than their accepted classmates to drop out of school, to engage in juvenile and adult criminality, and to also suffer from depression and anxiety as adults.

\section{Conclusion}

Learners' academic underachievement can sometimes be beyond the control of learners themselves. Apart from the individual-related factors, school-related factors and family-related factors can be responsible for the academic underachievement of learners. The literature review has focused mainly on the school-related factors that affect poor academic performance of learners. However, signs and types of academic underachievement were also included in this paper because they may be obvious within the school setting. School environment has an impact on the academic underachievement of learners. If the school environment is inadequate or impoverished, effective learning cannot take place. The quality and availability of instructional material, and the condition of buildings and facilities affect the way learners view school and learning. The effect of peers on academic underachievement was also discussed. Antisocial behaviour has a negative effect on the academic performance while pro-social behaviour normally has a positive effect on the academic performance. Examinations as a major tool assessment were also discussed. Learners tend to fail examinations because of the manner in which they are conducted.

\section{References}

Ansell, N. 2002. Secondary Education Reform in Lesotho and Zimbabwe and the Needs of Rural Girls: Pronouncements, Policy and Practice. Comparative Education, 38(1): 91-112.

Baker, J.A., Bridger, R. and Evans, K. 1998 Models of Underachievement among Gifted Preadolescents: The Role of Personal, Family and School Factors. Gifted Child Quarterly, 42(1): 5-15.

Bamgbose, A. 2000. Language and Exclusion: Consequences of Language Policies in Africa. London: transsaction.

Berk, L.E. 2002. Infants, Children and Adolescents. ( $4^{\text {th }}$ edition). Boston: Allyn and Bacon. 
Boyd, D and Bee, H. 2006. Lifespan Development. (4 ${ }^{\text {th }}$ edition). Boston: Pearson Education.

Brophy, J. and Alleman, J. 2007. Powerful Social Studies For Elementary Students. (2 ${ }^{\text {nd }}$ edition). United States: Wadsworth/ Thomson.

Bukatko, D. and Daehler, M.W. 2004. Child Development: A Thematic Approach. (5 $5^{\text {th }}$ edition). Boston: Houghton Nifflin.

Chaplain, R. 2003. Teaching without Description in the Primary School: A Model for Managing Pupil Behavior. New York: Routledge Flamer.

Child, D. 2004. Psychology and the Teacher. (7 $7^{\text {th }}$ edition). New York: Worth.

Connor, D.F. 2002. Aggression and Antisocial Behavior in Children and Adolescents: Research and Treatment. London: The Guilford Press.

Cooley, M.L. 2007. Teaching Kids with Mental Health \& Learning Diisorders in the Regular Classroom: How to Recognize, Understand, Help Challenged(and Unchallenged) Student Succeed. Minneapolis: Free Spirit Publishing.

Coon, D. 2002. Psychology: A Journey. Belmont: Wadsworth/ Thomson.

Cross, M., Mungadi, R. and Rouhani, S. 2002. From Policy to Practice:Curriculum Reform in South African Education (1). Comparative Education, 38 (2): $171-187$.

Dacey, J.S. and Travers, J.F. 2004. Human Development across the lifespan. Boston: McGraw- Hill.

Donald, D., Lazarus, S. and Lolwana, P. 2006. Educational Psychology in Social Context. (3 ${ }^{\text {rd }}$ edition). Cape town: Oxford University Press.

Education For All. 2000. South African Report. Pretoria: Department of Education.

George, P.S., McEwin, C.K. and Jenkins, J.M. 2000. The Exemplary High School. Fort Worth: Harcourt College Publishers.

Gibbsons, P. 2002. Scaffolding Langauge, Scaffolding Language: Teaching Second Language Learners in the Mainstream Classroom. Portmuoth: Heinemann

Hardiman, M.M. 2003. Connecting Brain Research With Effective Teaching: The Brain- Targetded Teaching Model. USA: Scarecrow.

Henley, M., Ramsey, R.S. and Algozzine, R.F. 2002. Characteristics of and Strategies for Teaching Students with Mild Diasdilities. $\left(4^{\text {th }}\right.$ edition). Boston: Allyn and Bacon.

Holt, L.C. and Kysilka, M. 2006. Instructional Patterns: Strategies for Maximizing Student Learning. New Delhi: SAGE.

Holt, L.C. and Kysilka, M. 2006. Instructional Patterns: Strategies for Maximizing Student Learning. New Delhi: SAGE.

Hong, E., Greene, M.T. and Higgins, K. 2006. Instructional Practices of Teachers in General Education Classrooms and Gifted Resource Rooms: Development and Validation of the Instructional Practice Questionnaire. Gifted Child Quarterly, 50(2): 102-103.

Kerry, T. and Wilding, M. 2004. Effective Clasroom Teacher: Developing the Skill You Need in Today's Classroom. Britain: Pearson Education.

Kizlik, B. 2009. Thinking Skills Vocabulary and Definitions. Retrieved September 17, 2009 from http:www.adprima.com

Landrum, T.J., Tankersley, M. and Kauffman, J.M. 2003. What is Special About Special Education for Students with Emotional or Behavioral Disorders? The Journal of Special Education, 37(3): 148-156.

Law, S. and Glover, D. 2002. Educational Leadership and Learning: Practice, Policy and Research. Buckingham: Open University Press.

Marcus, I.M. 2007. Personality Styles of Academic Underachievers. Retrieved May 01, 2009 from http://www.articlesbase.com

Mathews, M.S and McBee, M.T. 2007. School Factors and Underachievement of Gifted Student in a Talent Search Summer Program. Gifted Child Quarterly,

Mda, T.V. and Mothata, M.S. 2000. South Africa Education - After 1994. Kenwyn: Juta.

Mikami, A.Y., Boucher, M.A. and Humphreys, K. 2005. Prevention of Peer Rejection through Classroom-Level Intervention in Middle School. The journal of Primary Prevention, 26(1); 5-10.

MoET, 2005. Curriculum and Assessment Policy: Education for Individual and Social Development. Maseru: Government of Lesotho.

MoET, 2008. Curriculum and Assessment Policy: Education for Individual and Social Development. Maseru: Government of Lesotho.

Mokhele, P.R. 2006. The Teacher-learner Relationship in the Management of Discipline in Public High Schools. Africa Education Review, 3(1+2): 148-159.

Naidoo, M. 2006. 'Transition from Senior Certificate to the Further Education and Training Certificate'. In: Marking Matric: Colloquium Proceedings. Ed. By V. Reddy, Cape Town: HSRC Press, 10-17

Nairne, J.S. 2003. Psychology: The Adaptive Mind. (3 ${ }^{\text {rd }}$ edition). Belmont: Wadsworth/ Thomson Learning.

Olivier, M.A.J. 2006. The Impact of Deprived Enviroments on Learner Motivation. Africa Education Review, 3(2+1): 48-66.

Overall, L. and Sanster, M. 2003. Seconday Teacher's Handbook. New York: Continuum.

Pandor: Most Schools doing poorly. 2008, September 04. News - South Africa: 12. Retrieved March 02, 2009 from http://www.iol.co.za/

Papalia, D.E., Gross, D. and Feldman, R.D. 2003. Child Development: A topical approach. Boston: McGraw-Hill Higher Education.

Passer, M.W. and Smith, R.E. 2004. Psychology: The Science of Mind and Behaviour. (2 ${ }^{\text {nd }}$ edition). New York: McGraw-Hill.

Pastorino, E. and Doyle- Portillo, S. 2006. What is Psychology? Australia: Wadsworth/ Wadsworth.

Prah, K.K. 2005. Llangauge of Instruction for Education, Development and African Emancipation. In :Language of Instruction for African Emanicipation: Focus on Postcolonial Contexts and Considerations. Ed. By B. Brock-Utne and R.K. Hopson, Dar es Salaam: Nkuki Na Nyota, 23-49.

Rathus, S.A. 2006. Childhood in the New Millennium. (8 $8^{\text {th }}$ edition). Orlando: Harcourt College Publishers.

Rayneri, L.J., Gerber, B.L. and Wiley, P.L. 2006. The Relationship between Classroom Enviroment and The Learning Styles Preferences of Gifted Middle School Students and The Impact on Leaves of Performance. Gifted Child Quarterly, 50(2): 104-118

Reber, S. and Reber, E. 2001. The Pengiun Dictionary of Psychology. (3 ${ }^{r d}$ edition). London: Pengiun books.

Reddy, V. 2006. 'Introduction'. In: Marking Matric: Colloquium Proceedings.Ed. By V. Reddy, Cape Town: HSRC Press, xii-xxiv. 
Reis, S and McChoach, D. 2000. The Underachievement of Gifted Students: What Do We Know and Where do We Go? Gifted Child Quarterly, 44,(3): 152-170.

Reiss, S. 2008. The Normal Personality: A New Way of Thinking about People. New York: Cambridge University Press.

Santrock, J.W. 2003. Psychology. (7 ${ }^{\text {th }}$ edition). Boston: McGraw-Hill.

Smith, E. 2007. Analysing Underachievement in Schools: Empirical Studies in Education. New York: Continuum.

Sue, D., Sue, D.W. and Sue, S. 2003. Understanding abnormal Behaviour. ( $7^{\text {th }}$ edition).Boston: Houghton Mifflin Company.

Thurlow, M. 2003 'The Management of School'. In: Learner and Strategic Management in South Africa Schools. Ed. By M. Thurlow, T. Bush, and M. Coleman, London: Commonwealth Secretarist, 21-44.

Vaughn, S., Bos, C.S. and Schumm, J.S. 2007. Teaching Student who are Exceptional, Diverse, and at Risk in the General Education Classroom. (4th edition). Boston: Pearson.

Wearmouth, J. Richmond, R.C. Glynn, T. and Berryman, M. 2004. Understanding Pupil Behavior in School: A Diversity of Approaches. London: David Fulton.

Westminster Institute of Education. 2006. Underacheivement. Retrieved December 15, 2008 from http://www.brookees.ac.uk/

Woolfolk, A. 2005. Educational Psychology. (9 $9^{\text {th }}$ edition). Boston: Pearson Education.

World Data on Education. 2006. Lesotho. (6 ${ }^{\text {th }}$ edition). Retrieved October 20, 2009 from http://www.ibe.unesco.org/ 